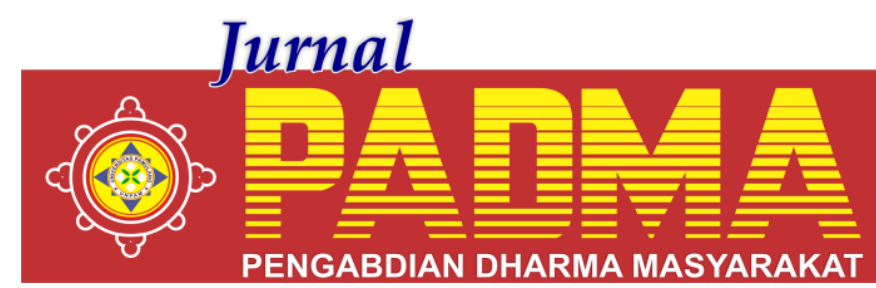

VOLUME 1, NOMOR 3, JULI 2021

\title{
EDUKASI BAHAYA COVID 19 \& IMPLEMENTASI PROTOKOL KESEHATAN DI MASJID AL-IKHLAS JAKARTA BARAT
}

\author{
${ }^{1 *}$ Ardi Cornelis, ${ }^{2}$ Erlansyah Pandji Anom, ${ }^{3}$ Selvy Sendari, ${ }^{4}$ Yolanda Andriani, \\ 5Yoel Gordon Saputra Walangare \\ Universitas Pamulang, Tangerang Selatan, Banten, Indonesia \\ *ardicornelis7@gmail.com
}

\begin{abstract}
Abstrak
Pandemi COVID-19 atau virus corona merupakan pandemi yang sedang dirasakan dampaknya oleh hampir seluruh Negara yang ada di Dunia. Dampak tersebut tidak hanya pada aspek keselamatan hidup masyarakat, melainkan dapat dirasakan pada aspek ekonomi politik terutama pada negara dunia ke tiga seperti Indonesia. Tidak sedikit upaya yang dilakukan oleh pemerintah pusat sampai hari ini namun belum memberikan efektivitas sebagaimana mestinya. Hingga akhirnya, pemerintah menerapkan kebijakan Kebiasaan Baru dalam beraktivitas sehari - hari yang disebut juga New Normal, Semenjak dimulainya era New Normal pada kondisi pandemi COVID - 19 masyarakat sudah dapat beraktivitas hampir seperti biasanya, namun dengan tetap menjalankan protokol kesehatan. Hanya saja yang terjadi sering kali masyarakat terutama pada masjid - masjid masih banyak jemaah yang kurang mematuhi aturan protokol kesehatan tersebut yang kemungkinan akibat kurangnya kesadaran diri dan juga fasilitas dan himbauan protokol kesehatan yang kurang digalakan.Tujuan dari penulisan ini adalah untuk memaparkan alternatif-alternatif yang perlu dilakukan untuk meningkatkan kesadaran masyarakat khususnya jemaah Masjid Al-Ikhlas Jakarta Barat akan bahayanya virus covid - 19 dan bagaimana mencegah penularannya melalui kiat - kiat PHBS atau Prilaku Hidup Bersih dan Sehat.
\end{abstract}

Kata Kunci: COVID-19, Protokol Kesehatan, Pandemi, New Normal, PHBS

\section{Abstract}

The COVID-19 pandemic or corona virus is a pandemic that is being felt by almost all countries in the world. The impact is not only on the aspect of the safety of people's lives, but can be felt in the political economy, especially in third world countries such as Indonesia. Not a few efforts have been made by the central government to date but have not provided the effectiveness as it should. Until finally, the government implemented a New Habit policy in daily activities which is also called New Normal. Since the start of the New Normal era during the COVID-19 pandemic conditions, people have been able to carry out activities almost as usual, but by still implementing health protocols. It's just that what often happens is that people, especially in mosques, are still many congregations who do not comply with the rules of the health protocol which may be due to a lack of self-awareness and also the lack of facilities and health protocol appeals. This needs to be done to increase public awareness, especially the congregation of Al-Ikhlas Mosque in West Jakarta about the dangers of the covid-19 virus and how to prevent its transmission through PHBS tips or Clean and Healthy Living Behavior.

Keywords: COVID-19, Health Protocol, Pandemic, New Normal, PHBS

\section{PENDAHULUAN}

Fungsi masjid sangat signifikan terhadap kehidupan manusia, sehingga masjid sangat ramai dikunjungi masyarakat, khususnya pada waktu-waktu tertentu. Jama'ah yang paling ramai mengunjungi masjid adalah jama'ah laki-laki. Sementara, laki-laki merupakan kelompok yang rentan terhadap COVID-19. Kondisi ini menjadi potensi penyebaran dan penularan COVID19. Untuk itu, perlu adanya manajemen masjid berbasis health transition pada masa pandemi COVID-19.

Tujuannya adalah untuk mencegah dan memutus rantai penyebaran COVID-19. Manajemen ini memasukkan elemen konsepsi sosial dan perubahan perilaku kaitannya dengan penentu-penentu kesehatan (health determinants). Manajemen ini meliputi : pertama, physical management yang terdiri dari kepengurusan, pembangunan dan 
pemeliharaan fisik masjid, pemeliharaan kebersihan masjid, pengelolaan fasilitasfasilitas masjid. Kedua, functional management yang meliputi fungsi masjid sebagai tempat dakwah, tempat pendidikan, dan tempat sosialisasi dan informasi tentang pencegahan penyebaran COVID-19.

Berdasarkan latar belakang tersebut, kami dari Tim Program Pengabdian Masyarakat (PKM) Universitas Pamulang (UNPAM) yang berjumlah 5 mahasiswa terpanggil untuk ikut serta dalam memberikan solusi persoalan yang dihadapi oleh Organisasi Masyarakat tersebut dengan judul PKM : “ Edukasi Bahaya Covid 19 \& Implementasi Protokol Kesehatan di Masjid Al-Ikhlas Jakarta Barat " agar masyarakat dapat lebih memiliki kesadaran akan bahaya virus covid 19 dan pentingnya perilaku hidup bersih dan sehat melalui implementasi protokol kesehatan.

Rumusan masalah dari analisis permasalahan di atas, yaitu

1. Bagaimana memberikan pengetahuan tentang Edukasi Bahaya Covid 19 kepada masyarakat.

2. Bagaimana memberikan arahan Implementasi Protokol Kesehatan kepada masyarakat.

Adapun Tujuan dari kegiatan pengabdian kepada masyarakat ini adalah untuk Memberikan pelatihan tentang Edukasi Bahaya Covid 19 \& Implementasi Protokol Kesehatan Di Masjid Al-Ikhlas Jakarta Barat. Sehingga akan dapat meningkatkan kesehatan di lingkungan masyarakat tersebut.

Manfaat yang diperoleh dari adanya kegiatan Pengabdian Kepada Masyarakat ini adalah :

1. Manfaat dari pihak akademik

Bagi pihak akademik secara tidak langsung fungsinya sebagai dimensi intelektual. Yaitu pengabdian kepada masyarakat, dan sebagai bahan referensi untuk membantu mahasiswa semester bawah yang akan menyusun proyek akhir serta menambah perbendaharaan buku dalam perpustakaan.

2. Manfaat bagi Masyarakat sekitar

Masyarakat dapat meningkatkan kewaspadaan, kebersihan dan kesehatan tubuh di wabah virus covid - 19 seperti saat ini.
3. Manfaat bagi peneliti lain

Bagi peneliti lain, diharapkan penelitian ini dapat menjadi sebuah rujukan bagi sivitas akademika yang ingin mengangkat penelitian sejenis.

\section{METODE}

Berdasarkan pendahuluan di atas, kami tim PKM dari Program Studi Manajemen Sumber Daya Manusia Universitas Pamulang memberikan penjelasan tentang edukasi kesehatan untuk pencegahan covid - 19 di lingkungan masyarakat. Selain itu tidak hanya sampai memberikan penjelasannya saja akan tetapi kami juga memberitahukan asal usul virus covid - 19, informasi kematian virus covid 19, memberitahukan tentang gejala virus covid - 19, memberitahukan tentang komplikasi infeksi covid - 19, memberitahukan tentang bagaimana corona virus merusak tubuh yang terinfeksi, memberitahukan panduan pelaksanaan ibadah di masjid sesuai dengan protokol kesehatan covid - 19 dan memberitahukan memakai masker dengan benar. Sehingga diharapkan bisa membantu warga setempat terhindar dari virus covid - 19. Hal yang akan kami bahas terkait masalah dan solusinya, sehingga dari materi yang akan dibahas dapat mencapai $100 \%$ persentase .

Dalam realisasi pemecahan masalah, kami membuat materi yang sudah menyesuaikan dengan kerangka pemecahan masalah yang ada. Mengingat bahwa pencegahan virus covid - 19 sangat penting untuk kesehatan warga setempat. Dari pelaksanaan kegiatan Pengabdian Kepada Masyarakat yang telah kami lakukan, terlihat sekali antusias dari para warga sekitar dalam menerima pemaparan materi. Para pengurus dapat dengan mudah menyampaikan informasi seputar edukasi kesehatan untuk pencegahan covid - 19 kepada masyarakat seperti memberi tahukan asal usul virus covid - 19, informasi kematian virus covid - 19, memberitahukan tentang gejala virus covid - 19, memberitahukan tentang komplikasi infeksi covid - 19, memberitahukan tentang bagaimana corona virus merusak tubuh yang terinfeksi, memberitahukan panduan pelaksanaan ibadah di masjid sesuai dengan protokol kesehatan covid - 19 dan 
memberitahukan memakai masker dengan benar. Sehingga dengan begitu, dapat dikatakan presentase ketercapaian pun sudah mencapai $100 \%$.

Sosialisasi dilakukan pada jemaah masjid Al-Ikhlas mengenai cara panduan protokol kesehatan untuk pencegahan virus covid - 19 untuk dilakukan sehari - hari dan khususnya pada saat melakukan ibadah di Masjid. Kegiatan pengabdian masyarakat kami juga di hadiri oleh ketua bidang SDM DKM Masjid Al-Ikhlas dan perwakilan warga sekitar.

Metode kegiatan yang digunakan adalah dengan cara survey dan kita mendatangai lokasi masjid Al-ikhlas dan akan memberikan informasi tentang edukasi bahaya covid 19 dan implementasi protokol kesehatan disana.

Persetujuan proposal pengabdian masyarakat pada kampus Universitas Pamulang dan Masjid Al-Ikhlas Jalan Sumbawa Raya Kav. PTB Kel. Tegal Alur Kota Jakarta Barat guna membekali para pengurus untuk Pencegahan virus covid - 19 .

Kegiatan ini meliputi bagaimana cara untuk para warga bisa menjaga kesehatannya dari virus covid - 19 ini dan menerapkan protokol kesehatan di dalam melaksanakan ibadah dimasjid.

Persiapan yang dilakukan adalah segala hal yang terkait dengan materi, bahan dan alat sesuai dengan tema secara baik. Hasil persiapan tersebut dimaksudkan agar materi tersampaikan dengan dan mudah dimengerti serta dipahami oleh ketua bidang SDM DKM Masjid Al-Ikhlas, para pengurus Masjid dan warga.

Materi yang kami bagikan dengan cara praktek langsung mengunakan laptop agar mudah dipahami oleh warga sekitar, kami pun secara bergantian menyampaikan informasi tentang virus covid - 19, menyampaikan informasi tentang gejala virus covid - 19 dan menyampaikan cara panduan protokol kesehatan dimasa pandemi virus covid - 19 .

\section{HASIL DAN PEMBAHASAN}

Kegiatan ini dilakukan Masjid AlIkhlas, Jalan Sumbawa Raya Kav.PTB, RT.6/RW.6, Kel. Tegal Alur, Kec. Kalideres, Kota Jakarta Barat. Yang dilakukan oleh peserta kegiatan yang terdiri dari mahasiswa
Universitas Pamulang, dosen pembimbing, masyarakat setempat yaitu ibu-ibu dan bapak-bapak setempat, para pengurus masjid Al-Ikhlas.

Adapun kegiatan dilaksanakan melalui penjekasan materi, diskusi, Tanya jawab, serta membimbing dalam upaya mengedukasi masalah yang sedang terjadi saat ini yaitu COVID-19. Kegiatan berjalan dengan baik dan lancar, serta masyarakat sangat berantusias dan semangat dalam mengikuti kegiatan.

Akibat pandemi ini pula, penggunaan masjid sebagai tempat ibadah juga menjadi dilema juga perhatian pemerintah agar tidak menjadi sumber penularan virus yang tinggi hingga akhirnya dikeluarkan aturan protokol kesehatan yang wajib diterapkan di semua rumah ibadah termasuk masjid. Atas dasar itu pula, kami melihat penggunaan rumah ibadah Masjid Al-Ikhlas masih kurang menerapkan protokol kesehatan dengan baik sehingga kami sosialisasikan kembali mengenai bahayanya Virus COVID-19 dan bagaimana pencegahan dan protokol kesehatannya.

Kami juga memberikan dukungan fasilitas protokol kesehatan seperti : Handsanitizer, Masker, Handsoap, juga Dispensernya yang diletakan dibeberapa titik sudut masjid.

Tak lupa sebagai bentuk semangat beribadah, kami juga memberikan 2 (dua) buah Al-Quran untuk menambah persediaan Kitab suci Al-Quran yang dipakai untuk kegiatan pengajian dan sedikit sumbangan dana untuk menambah dana perbaikan masjid.

\section{PENUTUP \\ Kesimpulan}

Adapun Kesimpulan yang dapat kita tarik dari pelaksanaan kegiatan Pengabdian Kepada Masyarakat oleh Universitas Pamulang yang dilakukan oleh kelompok kami telah berjalan dengan lancar dan mendapat sambutan hangat dari masyarakat Sumbawa Raya Kav. PTB, RT.06/RW.06, Kel. Tegal Alur, Kec. Kalideres, Kota Jakarta Barat.

Harapan kami dengan pengabdian ini dapat membantu Masyarakat lebih memahami lagi tentang bahaya covid 19. Dengan cara kami melakukan edukasi bahaya covid 19 dan implementasi protokol 
kesehatan ini bisa memberikan kewaspadaan tentang bahaya virus ini juga masyarakat lebih sadar akan pentingnya menjalankan protokol kesehatan dalam kesehariannya.

Akhirnya, kami mengucapkan terima kasih kepada seluruh pihak yang telah mendukung kegiatan yang kami laksanakan dan kami mohon maaf apabila dalam laporan ini banyak ditemukan kekurangan.

\section{Saran}

Affandi, A., Sarwani, A. S., Erlangga, H., Siagian, A. O., Purwanto, A., Effendy, A. A., ... \& Wahyitno, C. D. M. (2020). Optimization of MSMEs Empowerment in Facing Competition in the Global Market during the COVID-19 Pandemic Time. Systematic Reviews in Pharmacy, 11(11), 1506-1515.

Haque, M. G., Munawaroh, M., \& Sunarsi, D. (2020). Analysis of SMEs Culinary Marketing Strategy During Covid 19 Pancemic: A Study at "Sate Bebek Cilegon" Resto in Cilegon, Banten. International Journal of Education, Information Technology, and Others, 3(2), 447-451.

Muttaqin, H., Wahidin, K., Maulana, M., \& Juarsih, J. (2020). PEMBERDAYAAN JAMAAH

Nurjaya, N., Sunarsi, D., Effendy, A. A., Teriyan, A., \& Gunartin, G. (2021). Pengaruh Etos Kerja Dan Disiplin Kerja Terhadap Kinerja Pegawai Pada Dinas
1. Bagi pengurus masjid Al-Ikhlas agar lebih memperhatikan kewajiban jema'ah untuk mengikuti aturan protokol kesehatan di masjid \& juga memperhatikan ketersdiaan fasilitas protokol kesehatan untuk para jema'ah yang akan melakukan ibadah dimasjid.

2. Perlu adanya ketegasan kepada para jam'aah agar betul-betul menjalankan aturan protokol kesehatan.

\section{DAFTAR PUSTAKA}

Kehutanan Dan Perkebunan Kota Bogor. JENIUS (Jurnal Ilmiah Manajemen Sumber Daya Manusia), 4(2), 172-184.

PAKPAHAN, Roida; Fitriani, Yuni. Analisa Pemanfaatan Teknologi pemberdayaan jama'ah masjid menghadapi dampak coronavirus disease (covid 19).

Shodiqin, Asep and Aziz, Rohmanur and Dewi, Ratna and Fitriani, Putri Diesy (2020). Model

Sunarsi, D., Suryani, N. L., \& Jati, W. (2020). Covid-19 Pandemic Analysis Toward Productivity Giving Layoffs Effect in The Company of Industrial Sector around South Tangerang. Prosiding ICoISSE, 1(1), 472-481.

Yuangga, K. D., \& Sunarsi, D. (2020). Pengembangan media dan strategi pembelajaran untuk mengatasi permasalahan pembelajaran jarak jauh di pandemi covid-19. JGK (Jurnal Guru Kita), 4(3), 51-58. 